Politicians and Professionalisation in the Pacific Islands: Revisiting Self-

Regulation?

Original Article

Jack Corbett

State, Society and Governance in Melanesia

School of International, Political \& Strategic Studies

ANU College of Asia \& the Pacific

Australian National University

Canberra ACT 0200

AUSTRALIA

jack.corbett@anu.edu.au

Tel: +61 261258394

Fax: +61261255525

A slightly amended version of this paper is published in the journal Politics and Policy Volume 41, No. 6 (2013): 852-876.

Acknowledgements: I would like to thank Brij Lal, John Boswell, John Uhr, Terence Wood, Katy Le Roy and panel members at the International Political Science Association World Congress, Universidad Complutense de Madrid, 8-12 July 2012, and the journal's anonymous reviewers who provided helpful suggestions and comments on earlier versions of this paper. Any errors are of course my own. 


\title{
Politicians and Professionalization in the Pacific Islands: Revisiting Self- Regulation?
}

\begin{abstract}
In this article I examine the nature of political practice in the Pacific Islands against two dominant measures of professionalization: incentive and institutionalist. Drawing from a range of qualitative data-interviews with politicians, published life histories and observation - from across the region, I find that professionalization is largely unapparent against these measures. However, despite the likelihood that this absence will continue, the professional politician continues to be a standard against which political leadership in the Pacific is assessed and thus poses a significant problem for would-be-reformers. In response to this dilemma, I find that the older idea of self-regulating professional ethics, usually disregarded by proponents of these newer and more managerial measures, has more to offer than might first appear.
\end{abstract}

Keywords: Governance, Self-Regulation, Professionalization, Pacific Islands, Politicians, Democratisation

\section{Introduction}

Proponents of the good governance agenda in development theory and practice have persistently championed the ability of institutional reform to resolve many of the 'problems' endemic to politics and parliamentary practice in 'new' democracies. Central to this research and policy agenda is the figure of the professional politician. Professionalism and professionalization have a strong 
normative appeal in a variety of work contexts (Evetts, 396). In relation to politics in developing countries, the emphasis on professionalization arises at the intersection between two theoretical models of governance (for a detailed review of both arguements see Norris 2012). The first is concerned with advancing state capacity and seeks answers to persistent instability. The Asian Development Bank (Laking 2010, 52-56), for example, claims that politics in Pacific Island countries ${ }^{1}$ is characterised by intense localisation, with politicians spending too much energy addressing the needs of their constituents rather than producing 'better human development outcomes'. The second advocates democratisation and views governance challenges as arising from a crisis of legitimacy. For example, the Inter-Parliamentary Union's guide to good practice (Beetham 2006: xi \& 10) endorses '.. recovering public confidence in the integrity of parliamentarians, through enforceable codes of conduct and reforms in party funding' and '... adequate salary for members; register of outside interests and income, enforceable limits on transparency in election fundraising and expenditure.'

Despite deriving their theoretical logic from seemingly opposed beliefs about the appropriate role and function of government, the prospect that more professionalized political actors could improve development outcomes offers something to both camps. For believers in the 'state capacity' argument, professionalization makes it more likely that politicians will resist clientelistic impulses and institute unpopular but necessary reforms, which then increase public confidence in the rightness of rational-legal authority and by extension the state. For supporters of the 'democratisation' approach, professionalized

\footnotetext{
${ }^{1}$ In this article I am specifically referring to the independent and self-governing Pacific countries that are commonly split into three sub-regions of Melanesia (Fiji, Papua New Guinea, Solomon Islands, and Vanuatu), Polynesia (Cook Islands, Niue, Samoa, Tonga, and Tuvalu), and Micronesia (Federated States of Micronesia (FSM), Kiribati, Marshall Islands, Nauru and Palau).
} 
politicians display exemplary conduct by faithfully upholding parliamentary procedures and investing time and energy in their committee work. In doing so, they enhance the reputation of the legislature and increase its legitimacy in the eyes of the voting public.

So far so good. In addition, there is a degree of simultaneity in the suite of interventions both perspectives propose, which include: 1) electoral reforms to support the formation of political parties; 2) induction programs for new members and parliamentary staff; and 3) legislative reforms to strengthen oversight bodies and legislative capacity (see Coghill et al. 2012; Nguyen 2012; O'Brien et al. 2012; Pelizzo 2010; Rozzoli 2012; Stapenhurst and Pelizzo 2012). Similarly, the emphasis on strengthening political parties is primarily intended to enhance the power and autonomy of the executive, while stronger oversight bodies are designed to counterbalance elite excess.

So what is the problem? Scholars writing in the postcolonial tradition might argue such attempts are paternalistic, but calls for these types of reforms are often advocated most strongly by local elites - challenging crude 'insider-outsider' representations. For example, one of Papua New Guinea's (PNG) pre-eminent political figures, politician, minister, judge, diplomat and key participant in the writing of the country's constitution, Bernard Narokobi, persistently critiqued his political colleagues for what he viewed as flagrant abuse of democratic principles (see Narokobi 1983, 2004), and he is not alone. Channelling this appraisal, the Organic Law on the Integrity of Political Parties and Candidates (OLIPPAC), and changes to the electoral system (First-Past-the-Post to Limited Preferential Voting), are examples of attempts to manufacture stability in PNG via legislative means. These efforts attract strong support from international donors with the 
Australian-based Centre for Democratic Institutions (CDI) ${ }^{2}$ and the United Nations Development Program (UNDP) both actively working with parliaments across the Pacific region to improve governance outcomes via similar means.

The problem then cannot be blamed on the absence of reform efforts but rather on the inability of these attempts to deliver more professionalized politicians (for discussion see Kinyondo 2012; Kinyondo and Pelizzo 2013). So far, much of the extant literature on governance in the Pacific Islands seeks to explain why political practice in the region persistently deviates from standard liberal/modernist norms (for selected examples see Haque 2012; Morgan 2005; Reilly 2006; Saldanha 2004). This article takes a different approach. Firstly, I draw from over 100 in-depth biographical interviews with politicians from across the region, observation and other publicly available materials, including more than 40 published life histories of political leaders, ${ }^{3}$ to examine the nature of political practice, as experienced by politicians, against incentive and institutionalist measures of professionalization.

Professionalism or professionalization is a highly contested term that has preoccupied scholars, particularly those interested in the sociology of work, for decades (for review see Evetts 2003). I do revisit the perennial discussion about what does and does not constitute a profession (or even 'full' or 'semi' profession, see Abbott, 431) here but instead seek to assess political practice in the Pacific Islands against the above reform agenda. In this prevailing view, the need for greater professionalization of the political class tends to be couched in the

\footnotetext{
${ }^{2}$ The Centre for Democratic Institutions is funded by the Australian Agency for International Development: http://www.cdi.anu.edu.au/A\&C/about_cdi.htm (accessed 02/09/2013).

3 Interviews and observation were undertaken with politicians in Samoa, Fiji, Palau, FSM, Marshall Islands, Solomon Islands, PNG, Tonga, Kiribati and Nauru, and at regional meetings and with retired or transiting politicians in Australia and New Zealand.
} 
language of managerialism, accountability and performance - in the Pacific and other developing countries the assumption is that politicians lack the required professional competency, expertise and credibility to adequately fulfil their roles and maintain public trust. The focus then, in this definition, is less on the Weberian conceptualisation of politics ${ }^{4}$ - those who live 'for' politics - and more on engendering professional conduct via increased remuneration levels, working conditions, staff and resources (for discussion see Jones 2006, 638). For the purposes of this article I separate this managerial conception into two measures incentive and institutionalist - and find that against them professionalization is largely unapparent in the Pacific Islands. Indeed, these measures illustrate that aspects of political life are becoming less professionalized and closer to the Weberian classification of those who live 'for' politics.

Secondly, I question whether, against these incentive and institutionalist measures, professionalization is likely to occur in the future. Essentially, I find in the negative. However, I argue that, despite the absence of requisite preconditions, the normative appeal of professionalism means that the professional politician will continue to be an ideal standard against which political leadership in the region will be assessed. This poses, I believe, a significant problem for disciples of stronger incentive or institutionalist reforms - put simply, political practice will always fall short of the ideal standard and as a result politicians will persistently find their legitimacy questioned by appeals to more managerial forms of leadership (Abbott, 433).

\footnotetext{
${ }^{4}$ In his famous essay Politics as a Vocation Max Weber (1978 [1919]) distinguishes between politicians who live 'off' politics - it is their primary means of employment and income - and those who life 'for' politics - it something pursed in service of a cause, with material support largely drawn from private means (for discussion see Kelley Jr. 1998, 339). While Weber was explicitly writing about politicians in early $20^{\text {th }}$ Century Europe, parallels can be drawn with leadership practice in pre-colonial Pacific cultures. For example, Douglas Oliver's (1955) ethnography of the Siuai of Bougainville - particularly the chapter 'A Leader in Action' - could be interpreted as a description of a leader living 'for' politics.
} 
In response to this dilemma, I return to an older definition of professionalism synonymous with autonomy and occupational control of work and argue that it has more to offer this discussion than might first appear. In this perspective, which has traditionally been the basis from which lawyers and doctors have claimed to be professionals, professionalism is constructed from within not imposed from without (Evetts 2003, 410; Uhr 2012, 138). It is based on a community of practitioners establishing and regulating the standards against which to judge their performance and conduct. Importantly, this view recognises that, when compared with other 'professions', determining professional conduct for politicians is somewhat unique - there is no professional association or requisite tertiary training requirement for political actors (Abbott 1998, 431). Rather, what constitutes appropriate conduct is subject to perpetual negotiation (Uhr 2012, 137).

In recognising this, I challenge the assumption implicit in the above extract from the Inter-Parliamentary Union's guide to best practice - that if political leaders in the Pacific adopted incentive or institutionalist characteristics of a 'professional' politician, politics would be measurably better, devoid of scandal and corruption. Rather, I argue that self-regulation enables us to provide an account of how parliamentary conduct is created and modified collectively between electors and the elected, and among the different branches of government - an example of the 'many hands' thesis. ${ }^{5}$ Consequently, professionalism does not fit neatly within modernist ${ }^{6}$ precepts, or donor mandated definitions of corruption, but is instead

\footnotetext{
${ }^{5}$ In this context the 'many hands thesis' refers to the sharing of political responsibility between numerous actors including politicians and voters, the executive and the legislature, the judiciary and the bureaucracy (for discussion see Uhr 2012,145).

${ }^{6}$ For the purpose of this article the term modernist is employed to broadly describe various schools of thought that see history and progress in linear terms.
} 
based on perpetually messy, unpredictable and contingent circumstances that derive their meanings from local context and history.

\section{Monetary Incentives}

There is a popular perception that politicians become rich. But how many ex-politicians (or serving politicians) are rich? Many are struggling to survive because their businesses were destroyed by politics or they gave away most of what they earned as a politician - not as bribes but because they feel a Melanesian obligation and compassion for the situation many people are in (Papua New Guinean politician Dame Carol Kidu cited in Larmour 2008: 236).

Since Max Weber (1978 [1919]) first raised concerns about the rise of a 'political class', professionalization, as a theme, has become synonymous with charting change in the world's parliaments. Central to this research agenda are questions about whether politics is indeed becoming professionalized, and income generation is an obvious incentive for most professions. Incentive-based measures to the study of political careers are based on the assumption that few people are willing to lose money by being a politician (Borchert 2003, 18). Political professionals, Jens Borchert $(2010,35)$ argues, behave like members of any other occupation, actively shielding themselves and their colleagues from the influence of outsiders. In doing so, Borchert $(2003,7-8)$ maintains, they create structural preconditions for political professionalization. These preconditions, as both an historical process and as an explanation of contemporary incentives, include: 1) a reliable source of income in politics; 2) a realistic chance of maintaining a job; and 3) the chance of a career. 
The key measures for assessing professionalization in this framework are remuneration levels and employment exclusivity, manifest in an historical tipping point when politicians shift from being independently wealthy and therefore able to undertake political work as a part-time 'hobby', to when holding political office is a full-time job.

The argument that politicians seek their position to maximise personal financial reward is magnified in developing countries generally, and in the Pacific Islands in particular, as per capita incomes are relatively low. This fuels speculation that politicians are primarily motivated by greed, both for the lucrative salary and their capacity to siphon funds from the public purse. Certainly, parliamentary salaries can be financially rewarding, especially in those countries with a comparatively small private sector. Prior to self-government, the Congress of Micronesia, for example, offered the first high-profile, professionally salaried positions for Micronesians (Hezel 2007). Conversely, Vanuatu's inaugural Prime Minister, Father Walter Lini $(1980,26)$, recalls relying on friends, relatives and party supporters to sustain his family when he decided to quit his job to further the work of the Vanua'aku Pati, while others from that period reflect that initially parliamentary salaries were quite low.

Since independence, however, remuneration for legislators and parliamentarians has increased, along with associated perks - although the salaries of politicians in the Asia-Pacific region are low by global standards, both in relative and absolute terms (Behnke et al. 2008) - heightening speculation, amongst the public and politicians, that many seek political office for material gain. Members with business enterprises often claim that those without alternative sources of income seek political office because it provides higher wages. In turn, those members 
argue that businesspeople only seek election to further their commercial ventures. Younger members wonder whether older politicians pursue office to supplement their retirement incomes, while salaried candidates question the motivations of the previously unemployed. With campaign costs believed to be rising, politicians also speculate that some members may resort to unscrupulous means to recover their initial outlays once elected. In Western Melanesia, the ways politicians use their discretionary funding allocation generate frequent accusations of corruption and abuse (for discussion see Fraenkel 2011).

Two arguments counter this depiction of rampant greed. Firstly, while politicians' salaries are often greater than average per capita wages, most of the people elected to parliaments in the Pacific Islands are not average wage earners (Crocombe 2008, 403-473). Indeed, many maintain that they received better salaries before entering politics:

I was enjoying a pretty reasonable income level and a good lifestyle and I guess I am one of the silly people ... I gave up a F\$130,000 a year job for a F\$30,000 a year parliamentary salary. In any economic kind of table that is ludicrous ... You want to lose money go into parliament ... Okay, I mean if you attend all of the meetings and did all sorts of things there would be a few dollars for it but compared to what you are required to undertake to service the electorate it doesn't match, it just doesn't match. [Fijian politician]

Secondly, as alluded to in this interview extract, the costs associated with both running and maintaining a seat in parliament are believed to be rising, in part because constituents know how much politicians are getting paid: 
It is not a good salary, only AUD\$480 a fortnight and the people they beg you, ask for school fees [and so on] ... very expensive ... I run my business for my kids and I ration my food to feed my family and [pay] for their education. The money is not enough, the salary ... there are 6000 people on my home island ... they come for a bicycle ... electricity ... water. [IKiribati politician]

While salaries vary from country to country, politicians maintain that even if they sought to enrich themselves in politics, given these types of financial obligations, it is almost impossible to do so. Indeed, as the Kidu quote at the beginning of this section illustrates, many politicians leave politics destitute, their livelihoods and savings destroyed.

Finally, while salaries alone may not make politicians rich, corruption is also offered as an explanation for how politicians use their political positions and broader influence to maximise personal benefits. Certainly, accusations of corruption are synonymous with holding public office, and politicians in Pacific Island countries are no exception. While a version of the Kidu quote at the beginning of this section is the most common reflection on the capacity of individuals to make money in politics, it is hard to ignore that some of the region's longest serving and most high profile politicians have managed to carve out significant personal and commercial wealth. As a result, whether these leaders became wealthy because of their political influence, or in spite of it, attracts popular speculation and intrigue:

[In] a small community, the likelihood of a minister being accused of double-dipping or corrupt practices is very high. We have a minister ... and he runs a company ... and I don't know whether there is something 
funny going on but all of a sudden there is kind of a contractor going across to his company, and there is a company associated with his company winning a contract. It is either that is happening or we are just looking at it in a different way because [he is a minister now] ... [Cook Islands politician]

In an interview for The Review (March 1998, 24), veteran Fijian politician and successful businessman Sir James Ah Koy defended himself against calls that he should separate his business and political interests by arguing:

Being Minister of Finance is a distraction and an extreme disadvantage to my family, especially to my two sons who do a great job. But every time they make a judgement and they go into some business, people think it is me that is giving them ideas. Does becoming Minister of Finance mean I should close my family businesses?

Similar arguments have been made by former Prime Minister of PNG, Sir Julius Chan, who told Pacific Islands Monthly (December 1986, 19-21) that: 'I have been a businessman all of my life and have never made money in politics. At the end of the day it's the conscience that counts.' Conversely, former Prime Minister of Solomon Islands, Solomon Mamoloni, was regularly linked with corruption when alive but many of his family now live in modest circumstances. Christopher Chevalier (pers comm. April 2012) argues in his forthcoming biography that this can be partly explained by his reckless money management but also the innumerable requests for assistance and his wilful generosity - while large sums of money may have passed through his hands, it rarely stuck. 
The extent to which these accounts are plausible is contentious. As Peter Larmour $(2012,20)$ contends, there is much 'talk' and 'silence' about corruption in the Pacific, with actual instances harder to substantiate because corruption, by its nature, tends to be highly secretive. On the other hand, conjecture illustrates that assessing the side-benefits of being in politics, and the degree to which a politician's influence can benefit other areas of their life, is far from straightforward. A lawyer, for example, might find their profile enhanced by their involvement in parliament, increasing their legal work, while becoming a politician can bring heightened attention from investors and entrepreneurs. More generally, it reflects that politicians are often embedded within a variety of networks before entering parliament - it is often one of the reasons they are approached to run - and these networks do not desist upon taking office. Moreover, corruption is rarely something that is actively undertaken alone but is instead embedded within a host of relationships. As Larmour (2012, 24) illustrates, corruption by the powerful is often heavily criticised by Pacific Islanders, but many also actively participate.

In contrast to the predictability required to satisfy Borchert's (2003) second precondition for professionalization, fluidity is a commonly cited characteristic of politics in the Pacific Islands. Safe seats, for example, provided by Fiji’s pre-2006 racially-based electoral system, or by appointee positions to the Fijian Senate or the Tongan Assembly, are exceptions that highlight high levels of incumbent turnover (as much as 50 per cent in a number of countries, see Fraenkel 2009). Consequently, few politicians can take their re-election for granted. Winners with high margins at one election often see their results quickly reversed at the next, just as high spending candidates get beaten by those without financial clout. High 
chiefs lose to lesser chiefs, well-educated to illiterate, men to women (sometimes). ${ }^{7}$

While fluidity is the common pattern, it is also true that many politicians, particularly those of the independence generation, enjoyed, or continue to enjoy, extended tenures in parliament, secured by their profile as 'founding fathers' of their respective countries (Fraenkel 2009). In addition, while most contemporary politicians acknowledge the high levels of turnover, they claim not to be concerned by it - assured that they will hold their seat at the next election even if their colleagues will not. They express belief that they have served their constituents diligently and cite the meaningful achievements they have produced in their electorates to support this view.

The ability to make politics a career is the final precondition for Borchert (2003). As outlined above, for many long serving politicians in the Pacific Islands, politics has become a career. In particular, those of the independence generation have dominated the politics of their respective countries for several decades. Countries where there are multiple levels of government can also provide a hierarchy of positions, with politicians moving from local or provincial government to the national legislature, for example.

Political parties can also entrench stratification, with politicians in Samoa, Fiji and to a lesser extent Cook Islands - countries that have more prominent political parties - expressing what could be described as a progressive ambition for ministerial positions. Certainly ministers receive better pay and usually enjoy additional perks, including an office, car, staff and in some countries

\footnotetext{
${ }^{7}$ The percentage of women elected to parliaments in the Pacific Islands is amongst the lowest in the world.
} 
accommodation. Parties can also provide a degree of structure around preselection, although politicians often lament that this process is beset with cronyism and backroom deals. In a Presidential system, the chair of certain parliamentary committees and the position of speaker can serve a similar function. In contrast, in countries where political parties are less prominent, or non-existent, the ability to forge a 'career pathway', like Donald Searing's (1994) 'Ministerial Aspirant' for example, is often unapparent with the uncertainty created by regular reshuffles undermining attempts to forge a ministerial career. In such circumstances it is not uncommon for first-time members to receive portfolios, or even the office of Prime Minister, while old-hands sit on the backbench.

Against Borchert's (2003) three preconditions, the above discussion points to the absence of a professionalized 'political class' in Pacific Island countries. While salaries have increased since independence, the costs associated with financing a campaign and servicing an electorate offset material gains. Moreover, incumbent turnover and the relative absence of ancillary political positions undermine careerism. Since Weber, political parties are believed to encourage professionalization, and yet in Samoa, where the Human Rights Protection Party has enjoyed virtually uninterrupted power for three decades, politicians describe political practice in similar terms. This supports the Weberian view (see also Dorronsoro and Massicard 2005) that the catalyst for professionalization is increased bureaucratisation of the party organisation and ancillary political positions within the superstructure of state-based institutions, rather than the existence of coherent ideological groupings. Indeed, as I have argued elsewhere (Corbett 2012), strict leadership categorisations are often anathema in the Pacific Islands where individuals undertake multiple roles and the boundaries between the 
personal and the political are blurred - in small island states could it ever be otherwise?

\section{Career Pathways and Institutional Roles}

Despite the prevailing orthodoxy of monetary incentives as a key indicator in the analysis of professionalization trends, there are other ways scholars have sought to assess changes to parliamentary or legislative service over time, most of which can broadly be classified as institutionalist. In his book on the rise of the career politician, Peter Riddell (1996) argues that politics is increasingly becoming a profession in Britain, with the new governing class - successors to the hereditary aristocrats - treating their political work as a full-time job. The British Parliament, Riddell $(1996,262)$ observed, is:

... increasingly dominated by career politicians who have dedicated most of their adult lives to entering the Commons, staying there and advancing to become ministers or spokesmen ...

From this perspective, diversity of occupational backgrounds is one standard against which professionalization is measured (Abbott, 397). Reflecting a general pattern of enbourgoisement, above average education levels are a common characteristic of politicians the world over (Brannelly et al. 2011; Edinger 2010; Theron 2012). Therefore, it is unsurprising that both of these trends are also apparent in the Pacific Islands. However, while members of the independence generation were often part of a hand-picked cadre of leaders, many of whom were the first of their respective countries to undertake tertiary education, often overseas, this trend is changing. The formation in the early 1970 s of a regional university, now complemented by numerous other tertiary institutions and 
colleges, has broadened access to education, and by extension the backgrounds of those elected to parliament. In addition, most politicians also believe that occupational backgrounds are becoming increasingly diverse, with an emerging private sector more prominent. If expatriate land holders and commercial interests dominated colonial assemblies, and public servants (including doctors, school teachers and police), unionists, clergy and traditional leaders or chiefs were common at independence, then politicians from commercial and business backgrounds, along with those from accounting and legal professions, NGOs and the tertiary education sector, are now also entering the region's parliaments.

These two trends - broadening education and occupation - run contrary to most of the literature on professionalization which tends to find a narrowing of occupational backgrounds, with politics a 'first career' for many members (Weller and Fraser 1987). Despite some exceptions, notably members of the Tongan nobility, most politicians in the Pacific do not move straight from university into what Paul Cairney (2007) calls 'politics facilitating positions', but rather, emerge from a variety of networks and associations, including those directly related to their career and profession as well as family ties and membership in religious institutions.

Professionalism also denotes a certain level of commitment and is usually associated with full-time employment. Analysis of this aspect of parliamentary work typically focuses on length of service, age profile and legislative activities: volume and quality of lawmaking, and review and oversight functions (see Beckman 2007; Park 2006; Rosenthal 1996; Squire 1992). In the Pacific Islands, attendance in parliament is usually a minimum legal requirement with enforceable consequences but for many politicians, whether in government or opposition, in a 
presidential system or Westminster, the nature of constituency work is discretionary - determined by a combination of a politician's aims and the demands of voters. Although seeking to calculate or define when a politician is or is not working can be pointless. How, for example, would one classify attending a family or church function, both of which can be politically important in small island Pacific states where voters are often also friends and relatives. Moreover, it is debatable whether politicians need to be full-time. Members of Niue's Assembly, the Pacific's smallest political entity, are paid to attend parliament one or two days a month, although the Cabinet of four has a much heavier workload (Crocombe 2008, 435).

Ministerial posts are generally considered full-time - a reason some politicians cite for turning down positions - and also enjoy better equipped offices, vehicles, staffing allocations and other work related benefits. Despite the separation of ministerial positions from the legislature, many parliamentarians in the presidential systems of Palau and the FSM claim to work full-time. They point to the significant commitment required to research and draft bills - work usually undertaken by civil servants in a Westminster setup - in addition to their committee and constituent work. In all cases, however, there are exceptions, with most politicians juggling numerous commitments and roles. It is not uncommon to find a parliamentary office empty but the local doctor's surgery or legal practice full of petitioners, just as the capacity of these politicians to provide their 'professional' services pro-bono to constituents is often an accepted part of their representative work.

The availability of resources and technical expertise is another way of measuring professionalism (see Coghill et al. 2008; Kinyondo 2012; Park 2006; Rozzoli 
2012). Indeed, while the professionalization theme is avowedly a $20^{\text {th }}$ Century phenomenon, the idea of political work having a technical dimension is not without classical precedent. Plato's (1997 [n.d.]) Statesman, for example, is an expert, possessing the art of kingship, while Donald Morrison $(2001,241)$ argues that the life of an active and ambitious politician, like Pericles or Disraeli, occupies a central place in Aristotle's philosophy.

The dearth of library services and research staff is often cited as an impediment to greater professionalization, underscoring why many donor funded organisations like the World Bank, Commonwealth Parliamentary Association, UNDP and CDI undertake 'parliamentary strengthening' work. Political parties can provide some resources but for the most part, even in the case of the biggest parties, funding for research is minimal. Looking outside of parliament, at election time parties might provide a manifesto and a logo, they may have a headquarters and some campaign staff, but politicians usually resource their own campaigns and select their own campaign teams. Family networks tend to provide many of the functions of an electorate office, just as the 'screening' of candidates is achieved through a variety of mechanisms and institutions other than party bureaucracies.

When compared across time, it could be argued that parliamentary resources are increasing, following a linear modernisation narrative. Certainly, the profile of parliaments and politicians has changed since colonial legislatures: they have more members and exert greater influence. But are they 'better'? From an institutionalist perspective these characteristics denote that they should be and yet in his life of Fijian politician A.D. Patel, Brij Lal (1997, 180) questions this assumption by arguing that Fiji's pre-independence legislature represented a highpoint in both conduct and debate. Similarly, the general view amongst political 
commentators and donors in the Pacific region is that contemporary parliaments largely underperform, with the last consolidated regional round of Legislative Needs Assessments conducted by UNDP (Morgan and Hegarty 2003) noting that parliaments in the Pacific region are less than effective mechanisms of governance. Performance, in this instance, was assessed against the full range of institutionalist measures discussed here, including the power of the legislature and associated institutions (committees, ombudsman, auditors-general) relative to the executive, the capacity of politicians to comprehend legislation, the absence of registers of members' pecuniary interests, the incapacity of constituents to hold their politicians to account, inadequate parliamentary support services and low levels of women's representation.

\section{Discussion: Revisiting Self-Regulation?}

Against incentive and institutionalist measures, professionalization is largely unapparent in the Pacific Islands. Indeed, the most prominent historical example of a 'political class' is the Tongan nobility - although their influence on local politics has been altered by recent democratic reforms (for a comprehensive account see Campbell 2011). In either case, recognition of this absence is not new - it is implicitly contained in the literature that seeks ways to 'fix' political practice that has deviated from established liberal/modernist norms. Rather, this description provides some clues as to why political life has resisted, and is likely to continue to resist, pushes to incentivise or institutionalise professionalization. Put succinctly, salaries do not outstrip constituent demands, incumbency and career progression is rarely predictable, background characteristics are broadening not narrowing, bureaucratised political parties hold little sway with voters, members often juggle parliamentary work with other 'professional' activities, and 
resources and technical expertise are limited by geography and available government revenue. When combined with the unique features of politics in small island states - the importance of relatives and friends to election outcomes, for example, and the absence of the economies of scale required to finance institutionalised political parties (see Corbett 2013a) - it is hard to conceive of a scenario where these measures will be met in the near future. In which case, to echo Abel Kinyondo (2012), donor efforts are unlikely to see a substantive shift towards professionalization no matter how well they tailor their programs to local conditions.

There is an obvious normative dimension to this finding as professionalization trends are not the subject of universal admiration. As Kate Jones $(2006,638)$ highlights, the label 'professional politician' is rarely a compliment. In fact, many detractors blame much of the current discontent with politics and politicians in places like Europe and America on the increasing professionalization of public office from the 1970s onwards (for review see Hay and Stoker 2009). Exponents of this perspective argue for a return to a 'politics for amateurs' where decisionmaking is more collaborative, deliberative and participatory. In this scenario, the professional politician is unfavourably juxtaposed with romanticised political 'amateurs' from the past: the passionate or ideologically driven citizen-legislator, the dutiful landed gentry of the late 19th century, or the localised community activist.

Based on this critique, many of the practices commonly associated with deviance in the Pacific - personalisation, localisation and the absence of political bureaucratised parties - are in fact ideal. Conversely, the professional politician, in either an institutional or incentivist guise, continues to be the standard against 
which politics in the Pacific is measured both locally and internationally. Indeed, Edward Wolfers $(2011,49)$ makes the inverse argument to Hay and Stoker in his discussion of PNG's OLIPPAC reforms when he claims that attempts to engineer stability risk the formation of a political class, with a corresponding impact on the representative character of the legislature, its role as a mechanism for organic forms of community expression, and the promise of bottom-up political change.

Disagreement about the normative merits of 'professional' or 'amateur' politicians across this socio-economic divide illustrates the perpetual subjectivity of best practice models - there is no single ethical theory on which we can all agree (French 2011, 4). How then should we go about assessing the conduct of politicians if professionalization, when measured against incentive or institutionalist criteria, has endogenous limitations? One alternative is to revisit self-regulation. In contrast to incentive or rule compliance measures, this perspective is predicated on the hope that democratically elected politicians can be trusted (or at least that there is more to be gained from promoting real ethics than there is from empty formalism). Professional conduct, in this view, is a political matter best determined via political processes (Uhr 2012, 133).

We can define self-regulation in two main ways. In the first, resembling a version of Weber's (1978 [1919]) 'ethic of responsibility', leaders undertake actions that satisfy their conscience while elections function as a vehicle for persuading the public of the implicit rightness of their conduct. The self, from this perspective, is private while regulation is largely a matter of individual integrity which is, from time to time, tempered by the will of the electorate who remove those leaders deemed to be acting inappropriately. In this account, which mirrors practice in most democracies, democratic government is inherently self-regulating albeit 
there is an underlying and largely unresolvable tension between the implicit emphasis on equality and the elitist tendencies of professionalization (see Kane and Patapan 2012). Certainly, in contrast to other parts of the world, the importance on the individual actor in this version of self-regulation is of greater significance in much of the Pacific where parties play a minor role.

The second definition of self-regulation considers elections to be an insufficient means of curbing the actions of leaders, as Coghill et al $(2012,1)$ argue with reference to the related legal concept of fiduciary duty: ${ }^{8}$

... elections are necessarily crude and blunt instruments of accountability because of their infrequency and the fact that so many overlapping and partially conflicting interests, policies and values have to be reduced to a single decision on which candidate or party to vote for.

In particular, they contend that elections do not encourage long-term thinking about policy problems that affect future generations, and while their book is specifically concerned with climate change - a topic of great significance in the Pacific - it is not too much of a stretch to draw parallels with the aims of the development enterprise. From this perspective self-regulation can be understood as the standards by which parliament, as a body of legislators, defines and enforces ethical conduct (like the United Kingdom's House of Commons Code of Conduct and its Parliamentary Commissioner for Standards and the Committee on Standards and Privileges for example). Political professionalism, from this perspective, has a collective character that cannot be understood solely by investigating the actions of single politicians but rather recognises that "whole

\footnotetext{
8 'Fiduciaries', in this context, have a responsibility to preserve the interests of a person other than themselves (for discussion see Coghill et al 2012).
} 
webs of relationships influence the conduct of political actors' (Uhr 2012, 146) a version of the 'many hands' thesis. But, does this fluid and inter-subjective view of self-regulating 'professional ethics' provide a plausible way of understanding political practice in the Pacific?

Politicians have a range of views about what constitutes appropriate conduct. Some fall in line with the rule compliance measures favoured by public choice theorists and institutionalists. Others endorse anthropological and historical critiques of universalist norms, which they argue violate local values and practices. Narokobi emphasised the harmonisation of local practices and beliefs with Christian principles, and, as I have argued elsewhere (Corbett 2013b), the call for more ethical leadership in the Pacific is often articulated via Christian norms rather than the avowedly secular good governance agenda. Others, like Cook Islands Leader of the Opposition Wilkie Rasmussen, have called for code of conduct type arrangements. ${ }^{9}$

Attempts by politicians to define their own standards, usually via externally administered and legally enforceable leadership codes and their equivalents, seek to satisfy members of the public concerned with (mis)conduct and corruption in office (see Larmour 2012). Paradoxically, even some institutionalists acknowledge that these externally enforced ethical frameworks can heighten accusations of corruption (Rosenthal 2006), while many politicians concede little interest (or capacity) in abiding by them, even if they also support strengthening such measures in principle. Self-regulation, be it individual or collective, is also unpopular with most donors and would-be-reformers. The Inter-Parliamentary

\footnotetext{
9 Rasmussen recently made this call in an interview with Radio New Zealand International (http://www.rnzi.com/pages/news.php?op=read\&id=78438 20 August 2013, accessed 30/08/2013).
} 
Union (2006, 103), for example, argues that 'Self-regulation is often insufficient to effectively enforce ethics regulations'.

This description illustrates that, at the very least, what constitutes appropriate conduct is, in practice, heavily disputed. However, where the other two measures see this disagreement as a problem, a self-regulating approach considers perpetual debate about appropriate standards, undertaken against the backdrop of each country's unique history and traditions, as important and necessary. In which case, conduct depends as much on informal networks and what Mark Bevir $(2010,262)$ calls 'local reasoning' as it does on formal regimes - it is constantly being created and modified by social actors in response to circumstances in the world around them (Bevir 2010, 88). From this perspective, ethical politics confers a kind of 'professional autonomy' on politicians - similar to that granted to doctors or lawyers - and recognises that in addition to being held accountable by voters during elections, individual members are also answerable to their fellow public leaders.

Self-regulation is not a panacea. I acknowledge that in the absence of legalised enforcement such attempts may largely function as aspirational metaphors (Finn 2012, 39). ${ }^{10}$ Certainly, as John Uhr $(2012,151)$ argues, the approach is 'inevitably more uncertain and unpredictable,' and open to the possibility that morality will be trumped by self-interest and electoral survival. However, this does not mean it has no value - quite the opposite. Given the limits of formalised mechanisms that I have identified in the Pacific context, recognition that political conduct is one

\footnotetext{
${ }^{10}$ It could be argued, for example, that the absence of competing independent media outlets in the smallest Pacific states reduces the capacity of the electorate to regulate MPs, but, as I have illustrated elsewhere (see Corbett 2013a), social proximity and gossip often fulfil a similar function in a small island context.
} 
part of a much broader discussion about the norms and mores that govern human behaviour allows us to revalue self-regulation. Rather than a set of lifeless institutions, it is a vehicle for creating and sustaining debate about what constitutes desirable political conduct in a given context. Importantly, selfregulation remains open to the possibility of a more demanding version of consequentialism $^{11}$ - it aims to foster an environment where commendable deeds enhance the prospects of MPs winning elections for example - as politicians must publicly defend their actions against collective norms of their own making (Uhr $2012,140)$. As such, it does not reduce ethical conduct to enforceability but seeks to inspire leaders to conduct themselves admirably.

More work is required to better understand how self-regulation occurs in the Pacific. For example, in Samoa a recent decision by Prime Minister Tuilaepa Sailele Malielegaoi to retain his Minister of Finance, Faumuina Tiatia Liuga, despite claims (disputed by Faumuina) he misappropriated public funds, drew sharp critique from both the opposition and 19 members of his party who outlined their grievances in a letter, later published in the Samoa Observer, to the Prime Minister. ${ }^{12}$ Ultimately, an emergency caucus meeting and a secret ballot saved the minister's job but the circumstances surrounding this case, the reaction of MPs, and the public discussion that ensued, illustrates the inherently political and contingent nature of the norms that govern political conduct. But, we need to know more, including about how this incident will impact re-election campaigns in Samoa, and the aim of this article is to highlight the importance of these

\footnotetext{
${ }^{11}$ Consequentialism is an ethical doctrine that seeks to judge actions by their effects rather than adherence to rules.

12 The 19 HRRP MPs letter to the Prime Minister was published in the Samoa Observer on 19 May 2013 under the title 'HRPP "has collapsed"?'

(http://www.samoaobserver.ws/home/headlines/4930-hrpp-has-collapsed, accessed 30/08/2013).
} 
instances to our understanding of the practice of politics in the Pacific and prompt closer examination of this and other similar cases.

\section{Conclusion}

[People say] '... politicians are corrupt, politicians are dirty, politicians are crooked', [but] no matter whatever you say, people will still like you. Let me tell you one example. You know waste matter, human waste? ... It is very attractive to flies. It is a classic example of who we are. Although you say that we are rubbish, flies will still fly all over us: they like it. So, no matter how much negative description [we get], I tell you my brother, people will still be rushing to see us [laughter] ... I [have] got a long list of people waiting to see me. [Solomon Islands politician]

The accusation of unprofessional behaviour is something politicians in the Pacific Islands share with their colleagues from around the world despite the differences in size of parliaments and populations, and the problems of capacity synonymous with labels like development. Reweighted incentives and stronger institutional mechanisms will, advocates argue, combat political misconduct and corruption and enhance the legitimacy of the legislature. And yet the impact of these programs in the Pacific region has been mixed at best (Kinyondo 2012; Kinyondo and Pelizzo 2013).

In this paper I have explored how appeals to professionalization are used to analyse the practice of politics in the Pacific Islands. I found that against incentive and institutionalist measures some aspects of political life are becoming professionalized, yet largely politicians do not emerge from or form an entrenched 'political class'. Indeed, with sectoral backgrounds generally broadening, in some 
Pacific Island countries facets of political life are moving closer to the Weberian classification where independently wealthy elites live 'for' politics. However, while helpful in understanding how life in parliament has changed over recent decades, and varies between countries, I have also highlighted the dilemma that this relative absence of necessary monetary or institutional preconditions presents to champions of formalistic measures of professionalism. Specifically, I have argued that donor efforts are unlikely to see a substantive shift against these measures no matter how well they tailor their programs to local conditions.

In response, I have considered how the idea of self-regulating professional ethics offers one potential solution to this problem. In addition to the inherently selfregulating nature of democratic government, I have argued for the need to revisit a collective view of professional ethics where conduct is constantly created and modified by social actors against the backdrop of unique histories and traditions. To be clear, I am not advocating the abandonment of support for parliamentary capacity building in the Pacific: we might decide that increasing institutional capability - resources and salaries - is intrinsically desirable. Nor am I blind to the limitations of a self-regulating approach - certainly it is partly contingent on 'free and fair' elections, for example - and the need for more research in this area that analyses how self-regulation works in practice. However, these caveats aside, I do maintain that revisiting self-regulation offers an important corrective to the current debate by recognising that the conduct of politicians is fundamentally created and sustained by webs of relationships that, as the above quote illustrates, are shaped by political processes - professional standards for politicians do not exist outside of politics but are implicitly the subjects of everyday political activity. 


\section{Bibliography}

Abbott, A. 1998. "Professionalism and the Future of Librarianship." Library trends. 46(3): 430-443.

Beckman, L. 2007. "The Professionalizationof Politics Reconsidered: A Study of the Swedish Cabinet 1917-2004." Parliamentary Affairs 60(1):66-83.

Beetham, D. 2006. Parliament and Democracy in the Twenty-First Century: a guide to good practice. Geneva, Switzerland: Inter-Parliamentary Union.

Behnke, K, A Hamilton, L Pagnac and P Terrazas. 2008. "The Dynamics of Legislative Rewards: An Empirical Analysis of Commonwealth Countries for the World Bank Institute." London School of Economics.

Bevir, M. 2010. Democratic Goverance. Princeton and Oxford: Princeton University Press.

Borchert, J. 2003. "Professional Politicians: Towards a Comparative Perspective." In The Political Class in Advanced Democracies, eds. J Borchert and J Zeiss. Oxford: Oxford University Press.

Borchert, J. 2010. "The Never Ending Trouble With Democratic Elitism." In Democratic Elitism: Comparative and Theoretical Perspectives, eds. H Best and J Higley. Leiden and Boston: Koninklijke Brill NV.

Brannelly, L, L Lewis and S Ndaruhuste. 2011. "Learning and Leadership: Exploring the linkages between higher education and developmental leadership." Developmental Leadership Program Research Paper 18.

Cairney, P. 2007. "The Professionalizationof MPs: Refining the 'PoliticsFacilitating' Explanation." Parliamentary Affairs 60(2):212-233.

Campbell, I. 2011. Tonga's Way to Democracy. Christchurch: Herodotus Press.

Chevalier, C (2012, April) E-mail message to the author.

Coghill, K, P Holland, R Donohue, K Rozzoli and G Grant. 2008. "Professional Development Programmes for Members of Parliament." Parliamentary Affairs 61(1):73-98.

Coghill, K, C Lewis and K Steinack. 2012. "How Should Elected Members Learn Parliamentry Skills: An Overview." Parliamentary Affairs 65(3):505-519.

Coghill, K, C J Sampford, and T Smith eds. 2012. Fiduciary duty and the atmospheric trust, Ashgate Publishing, Ltd.

Corbett, J. 2012. "'Two Worlds?' Interpreting Leadership Narratives in the 20th Century Pacific." Journal of Pacific History 47(1): 69-91.

Corbett, J. 2013a. "'Everybody Knows Everybody': Practising Politics in the Pacific Islands." Democratization. Advance Access published August 1 2013: DOI: $10.1080 / 13510347.2013 .811233$. 
Corbett, J. 2013b. "'A Calling From God': Politicians and Religiosity in the Pacific Islands." Global Change, Peace and Security. Advance Access published July 9 2013: DOI: 10.1080/14781158.2013.810616

Crocombe, R. 2008. The South Pacific. 7th Edition. Suva, Fiji: IPS Publications, University of the South Pacific.

Dorronsoro, G and E Massicard. 2005. "Being a Member of Parliament in contemporary Turkey." European Journal of Turkish Studies (Thematic Issue 3).

Edinger, M. 2010. "Elite Formation and Democratic Elitism in Central and Eastern Europe: A Comparative Analysis." In Democratic Elitism: New Theoretical and Comparative Perspectives, eds. H Best and J Higley. Leiden and Boston: Koninklijke Brill NV.

Evetts, Julia. 2003. "The Sociological Analysis of Professionalism Occupational Change in the Modern World." International sociology 18 (2): 395-415.

Finn, P. 2012. "Public Trusts and Fiduciary Relations." In Fiduciary Duty and the Atmospheric Trust, ed. K Coghill, CJ Sampford \& T Smith. Ashgate Publishing, Ltd.

Fraenkel, J. 2009. "Oceania's Political Institutions and Transitions." In Pacific Ways: Government and Politics in the Pacific Islands, ed. S Levine. Wellington: Victoria University Press.

Fraenkel, J. 2011. "The Atrophied State: A Supply-Side Perspective on Politician "Slush Funds" In Western Melanesia." In The Political Economy of Economic Reform in the Pacific, ed. R Duncan. Mandaluyong City, Philippines: Asian Development Bank.

French, R. 2011, "Public Office and Public Trust", Seventh Annual St Thomas More Forum Lecture, Canberra, 22 June, http://www.hcourt.gov.au/assets/publications/speeches/currentjustices/frenchcj/frenchcj22jun11.pdf

Haque, T. A. 2012. "The Influence of Culture on Economic Development in Solomon Islands: A Political-Economy Perspective." State Society and Governance in Melanesia Discussion Paper 1.

Hay, C and G Stoker. 2009. "Revitalising Politics: Have We lost the Plot?" Representation 45(3):225-236.

Hezel, F. 2007. "Island Politics." Micronesian Counsellor (67).

Jones, K. 2006. "One Step at a Time: Australian Parliamentarians, Professionalism and the Need for Staff." Parliamentary Affairs 59 (4): 638-53.

Kane, J and H Patapan. 2012. The Democratic Leader: How Democracy Defines, Empowers, \& Limits its Leaders. Oxford: Oxford University Press. 
Kelley Jr, S. 1998. "Politics as a Vocation: Variations on Weber." In Politicians and Party Politics, ed. JG Geer. Baltimore and London: The Johns Hopkins University Press.

Kinyondo, A. 2012. "Return on Training and Investment in Parliaments: The Need for Change in the Pacific Region." Parliamentary Affairs 65 (3):576-592.

Kinyondo, Abel, and Riccardo Pelizzo. 2013. "Strengthening Legislatures: Some Lessons from the Pacific Region." Politics \& Policy 41(3): 420-46.

Laking, R. 2010. State Performance and Capacity in the Pacific. Mandaluyong City, Philippines: Asian Development Bank.

Lal, B. V. 1997. A Vision for Change : A.D. Patel and the Politics of Fiji.

Canberra National Centre for Development Studies.

Larmour, P. 2008. "Corruption and the concept of 'Culture': Evidence from the Pacific Islands." Crime, Law, and Social Change 49:225-239.

Larmour, P. 2012. Interpreting Corruption: Culture and Politics in the Pacific Islands. Honolulu: University of Hawaii Press.

Lini, W. 1980. Beyond Pandemonium: From the New Hebrides to Vanuatu. Wellington Asia Pacific Books.

Morgan, M. 2005. "Cultures of Dominance: Institutional and Cultural Influences on Parliamentary Politics in Melanesia." State, Society and Governance in Melanesia Discussion Papers 2.

Morgan, M and D Hegarty. 2003. "Strengthening Pacific Parliaments: Legislative Reform Program for Pacific Island Countries." Suva: UNDP-GOLD.

Morrison, D. 2001. "Politics as a Vocation, According to Aristotle." History of Political Thought XXII(2):221-241.

Narokobi, B. 1983. Life and Leadership in Melanesia. Port Moresby: Institute of Papua New Guinea Studies.

Narokobi, B. 2004. "Parliamentary Reform for Good Governance." In

Governance Challenges for PNG and the Pacific Islands, ed. N Sullivan. Madang, Papua New Guinea and Canberra, Australia: The State, Society and Governance in Melanesia Program and Devine Word University.

Nguyen, L D. 2012. "Training for Elected Representatives in Vietnam: Context, Approach, Process." Parliamentary Affairs 65(3):640-657.

Norris, P. 2012. Making Democratic Governance Work: How Regimes Shape Prosperity, Welfare, and Peace. Cambridge: Cambridge University Press.

O'Brien, M, R Stapenhurst and B Prater. 2012. "World Bank Institute's Approach to Parliamentary Capacity Strengthening." Parliamentary Affairs 65(3):593-607. 
Oliver, D. 1955. A Solomon Island Society: Kinship and Leadership among the Siuai of Bougainville. Cambridge, MA: Harvard University Press.

Park, C. W. . 2006. "Professionalization and Policy Activism of the National Assembly in Newly Democratized Korea: Two Things Moving in Tandem?" International Political Science Association World Congress (Research Committee for Legislative Specialists). Fukuoka, Japan.

Pelizzo, R. 2010. "Public Accounts Committees in the Pacific Region." Politics and Policy 38(1):117-137.

Solomon, S (1986, December) "The Business of Politics." Pacific Islands Monthly Sydney: Pacific Publications.

Plato. 1997 [n.d.]. "Statesman." In Plato, Complete Works, ed. J. M Cooper. Indianapolis: Hackett Publishing Company.

Reilly, B. 2006. "Political Reform in Papua New Guinea: testing the evidence." Pacific Economic Bulletin 21(1):2006.

Riddell, P. 1996. Honest Opportunism: How We Get The Politicians We Deserve London: Indigo.

Rosenthal, A. 1996. "State Legislative Development: Observations from Three Perspectives " Legislative Studies Quarterly 21(169-98).

Rosenthal, A. 2006. "The Effects of Legislative Ethics Law: An Institutional Perspective." In Public Ethics and Governance: Standards and Practices in Comparative Research, eds. D Saint-Martin and F Thompson: Emerald Group Publishing.

Rozzoli, K. 2012. "Assisting Parliamentarians to Develop Their Capacities: Experiences from Working in Indonesia and the South Pacific." Parliamentary Affairs 65(3):628-639.

Saldanha, C. 2004. "Strategies for Good Goverannce in the Pacific." Asian-Pacific Economic Review 18:30-43.

Searing, D. 1994. Westminster's World. Cambridge, Massachusetts and London, England: Harvard University Press.

Squire, P. 1992. "Legislative Professionalism and Membership Diversity in State Legislatures." Legislative Studies Quarterly 13:65-82.

Stapenhurst, R and R Pelizzo. 2012. "Improving Democracy and Accountability in Ghana: The Importance of Parliamentary Oversight Tools." Governance 25(2):335-346.

Theron, M. 2012. "Emerging and Non-Emerging African Countries: A Statistical Exploration of the Leadership Factor." Developmental Leadership Program Research Paper 19. 
Interview (1998, March) "Playing God to the Nation." The Review. Suva, Fiji: Associated Media.

Uhr, J. 2012. "Professionalising Corruption? Investigating professional ethics for politicians." In Corruption: Expanding the Focus eds. M Barcham, B Hindess and P Larmour. Canberra: ANU E Press.

Weber, M. 1978 [1919]. "Politics as a Vocation." In Max Weber: Selections in Translation, ed. W.G. Runciman: Cambridge University Press.

Weller, P and S Fraser. 1987. "The Younging of Australian Politics or Politics as a First Career." Australian Journal of Political Science 22(2):76-83.

Wolfers, E. 2011. "Security, Good Governance, and the OLIPPAC." In The Quest for Integrity of Political Parties and Governance in Papua New Guinea: Law, Experience, and Issues, eds. E Wolfers, O Sepoe, R Anere and J Robins. Port Moresby, Papua New Guinea: Integrity of Political Parties and Candidates Commission. 